\title{
COVID-19 and Laparoscopic Surgery: Scoping Review of Current Literature and Local Expertise
}

Robert Adrianus de Leeuw ${ }^{1}$, MD, PhD; Nicole Birgit Burger ${ }^{1}$, MD, PhD; Marcello Ceccaroni ${ }^{2}$, MD; Jian Zhang ${ }^{3}$, MD; Jurriaan Tuynman ${ }^{4}, \mathrm{MD}, \mathrm{PhD}$; Mohamed Mabrouk ${ }^{5}, \mathrm{MD}, \mathrm{PhD}$; Pere Barri Soldevila ${ }^{6}, \mathrm{MD}$, PhD; Hendrik Jaap Bonjer $^{4}$, MD, Prof Dr; Pim Ankum ${ }^{7}, \mathrm{MD}, \mathrm{PhD}$; Judith Huirne ${ }^{7}$, MD, Prof Dr

\footnotetext{
${ }^{1}$ Amsterdam University Medical Center, Vrije Universiteit Amsterdam, Amsterdam, Netherlands

${ }^{2}$ Department of Obstetrics and Gynecology, Gynecologic Oncology and Minimally-Invasive Pelvic Surgery, International School of Surgical Anatomy, Istituto Di Ricovero e Cura a Carabettere Scientifico Sacro Cuore Don Calabria Hospital, Negrar di Valpolicella, Verona, Italy

${ }^{3}$ Department of Obstetrics and Gynecology, International Peace Maternity and Child Health Hospital, School of Medicine, Shanghai Jiaotong University, Shanghai, China

${ }^{4}$ Department of Surgery, Amsterdam University Medical Center, Vrije Universiteit Amsterdam, Amsterdam, Netherlands

${ }^{5}$ Cambridge Endometriosis and Endoscopic Surgery Unit, Cambridge University Hospitals NHS Foundation Trust, Addenbrook, United Kingdom

${ }^{6}$ Dexeus Mujer, Hospital Universitari Dexeus, Barcelona, Spain

${ }^{7}$ Department of Gynecology and Obstetrics, Research Institute Reproduction and Development, Amsterdam University Medical Center, Vrije Universiteit Amsterdam, Amsterdam, Netherlands
}

\section{Corresponding Author:}

Robert Adrianus de Leeuw, MD, PhD

Amsterdam University Medical Center

Vrije Universiteit Amsterdam

Boelelaan 1117

Amsterdam, 1081HV

Netherlands

Phone: 31618390269

Email: r.a.deleeuw@amsterdamumc.nl

\section{Abstract}

Background: The current coronavirus disease (COVID-19) pandemic is holding the world in its grip. Epidemiologists have shown that the mortality risks are higher when the health care system is subjected to pressure from COVID-19. It is therefore of great importance to maintain the health of health care providers and prevent contamination. An important group who will be required to treat patients with COVID-19 are health care providers during semiacute surgery. There are concerns that laparoscopic surgery increases the risk of contamination more than open surgery; therefore, balancing the safety of health care providers with the benefit of laparoscopic surgery for the patient is vital.

Objective: We aimed to provide an overview of potential contamination routes and possible risks for health care providers; we also aimed to propose research questions based on current literature and expert opinions about performing laparoscopic surgery on patients with COVID-19.

Methods: We performed a scoping review, adding five additional questions concerning possible contaminating routes. A systematic search was performed on the PubMed, CINAHL, and Embase databases, adding results from gray literature as well. The search not only included COVID-19 but was extended to virus contamination in general. We excluded society and professional association statements about COVID-19 if they did not add new insights to the available literature.

Results: The initial search provided 2007 records, after which 267 full-text papers were considered. Finally, we used 84 papers, of which 14 discussed severe acute respiratory syndrome coronavirus 2 (SARS-CoV-2). Eight papers discussed the added value of performing intubation in a low-pressure operating room, mainly based on the SARS outbreak experience in 2003 . Thirteen papers elaborated on the risks of intubation for health care providers and SARS-CoV-2, and 19 papers discussed this situation with other viruses. They conclude that there is significant evidence that intubation and extubation is a high-risk aerosol-producing procedure. No papers were found on the risk of SARS-CoV-2 and surgical smoke, although 25 papers did provide conflicting evidence on the infection risk of human papillomavirus, hepatitis B, polio, and rabies. No papers were found discussing tissue extraction or the deflation risk of the pneumoperitoneum after laparoscopic surgery. 
Conclusions: There seems to be consensus in the literature that intubation and extubation are high-risk procedures for health care providers and that maximum protective equipment is needed. On the other hand, minimal evidence is available of the actual risk of contamination of health care providers during laparoscopy itself, nor of operating room pressure, surgical smoke, tissue extraction, or $\mathrm{CO}_{2}$ deflation. However, new studies are being published daily from current experiences, and society statements are continuously updated. There seems to be no reason to abandon laparoscopic surgery in favor of open surgery. However, the risks should not be underestimated, surgery should be performed on patients with COVID-19 only when necessary, and health care providers should use logic and common sense to protect themselves and others by performing surgery in a safe and protected environment.

(JMIR Public Health Surveill 2020;6(2):e18928) doi: 10.2196/18928

\section{KEYWORDS}

laparoscopy; COVID-19; surgical procedures, operative; corona 2019; surgery; pandemic; outbreak; infectious disease; health care provider; physician

\section{Introduction}

\section{Background}

Coronavirus disease (COVID-19) is spreading worldwide, and all health care workers are affected by it [1]. At the moment of writing, the World Health Organization estimated over 2.5 million confirmed cases of COVID-19 and over 175 thousand deaths [2]. It is estimated from the Chinese outbreak that the risk of death is as high as $12 \%$ in epicenters of the epidemic and as low as $1 \%$ in less severely affected areas. This large difference may be due to a breakdown of the health care system in the epicenter, enhanced public health interventions, and enhanced hygienic measures [3].

According to Médecins Sans Frontières, nearly 1700 healthcare providers have been infected, representing $8 \%$ of the total COVID-19 cases in Italy, despite all preventive measures [4]. Therefore, health care providers are the highest risk group for infection, severe illness, and intensive care admission. This stresses the incredible importance of protecting this group.

Due to the combination of increased risk of individual infection and the effects of a breakdown of the healthcare system, it is even more relevant to discuss how to properly protect health care providers. If no personal protective equipment is available, health care workers will be jeopardized [5,6]. Moreover, the shortage of supplies is forcing management to make difficult decisions as to where supplies should be allocated and who needs them most in a hospital.

So, who is at risk? According to the US Centers for Disease Control and Prevention, all health care providers that are in direct contact with infectious secretions from a patient with COVID-19 are at risk. Secretions at risk for viral transmission include sputum, serum, blood, feces, and especially respiratory droplets $[7,8]$. Health care providers are all recommended to wear personal protective equipment (PPE). The risk increases with exposure to aerosol-generating procedures for at least 10 minutes at a distance of fewer than 2 meters from the patient [9]. Studies have shown that procedures such as endotracheal intubation, extubation, noninvasive ventilation, and exposure to aerosols in an open circuit are associated with high risk of viral transmission. Guidelines about the PPE needed in these situations are receiving increasing attention [10].
According to Wong et al [11], the main risk groups in the operating theater are those who cannot cancel or delay elective procedures. Foremost, of course, are anesthesiologists; however, departments such as intervention radiology, obstetrics, and cardiothoracic surgery are also at risk. Many acute surgical interventions are performed by laparoscopy; however, very little is written about the risks for health care providers of performing laparoscopic surgery on a patient with COVID-19. There is a debate in the literature whether open surgery is safer for health care providers compared to laparoscopic surgery [12,13].

The objective of this study is to provide an overview of potential contamination routes and possible risks for health care providers, and propose research questions based on current literature and expert opinions about laparoscopic surgery on patients with COVID-19.

\section{Theoretical Contamination Routes During Laparoscopic Surgery}

Before we can elaborate on the theoretical contamination routes, we must first discuss the contamination agents. The agents of contamination can be divided into three groups: those with proven infectious transmission, such as droplets, close contact, and aerosol transmission [14]; those with proven RNA presence, but no proven contamination yet, such as feces, inanimate surfaces, and blood $[8,15,16]$; and unknown or highly debated agents or even the presence of RNA, such as urine and amniotic fluid [8]. It should be noted that many studies are underway to determine which of these agents are, in addition to containing virus RNA, are also infectious. Taking these agents into consideration, there are several theoretical contamination routes by which health care providers can be infected by a COVID-19 positive patient.

Figure 1 shows potential viral contamination routes in the IR during laparoscopic surgery. The first and most discussed contamination route is intubation and extubation [17]. At this moment, the patient will excrete the most virulent respiratory secretions. The second risk is smoke and air evacuation during surgery [18]. During laparoscopy, smoke and aerosols are generated, not only by cauterization of blood vessels but also by dissection. This smoke can contain virulent DNA and RNA and is sometimes evacuated directly into the overpressured operating room (OR) by opening a valve on a trocar. The third contamination risk is tissue extraction [19]. Removing tissue, 
such as an appendix, bowel segment, gallbladder, cyst, or ectopic pregnancy, can cause excretions to be expelled from the body; the higher abdominal pressure from laparoscopy creates aerosols from excretions such as blood and mucus. The fourth moment at risk for contamination is at the end of the surgery, when the

Figure 1. Contamination routes during laparoscopy. OR: operating room. abdominal pressure is released by desufflation [19]. All the air, possibly filled with virulent DNA and RNA, is released into the air of the OR, usually under relatively high pressure. A fifth risk factor can be the positive air pressure in the OR, which pushes aerosols out of the OR into hallways and other ORs [17].

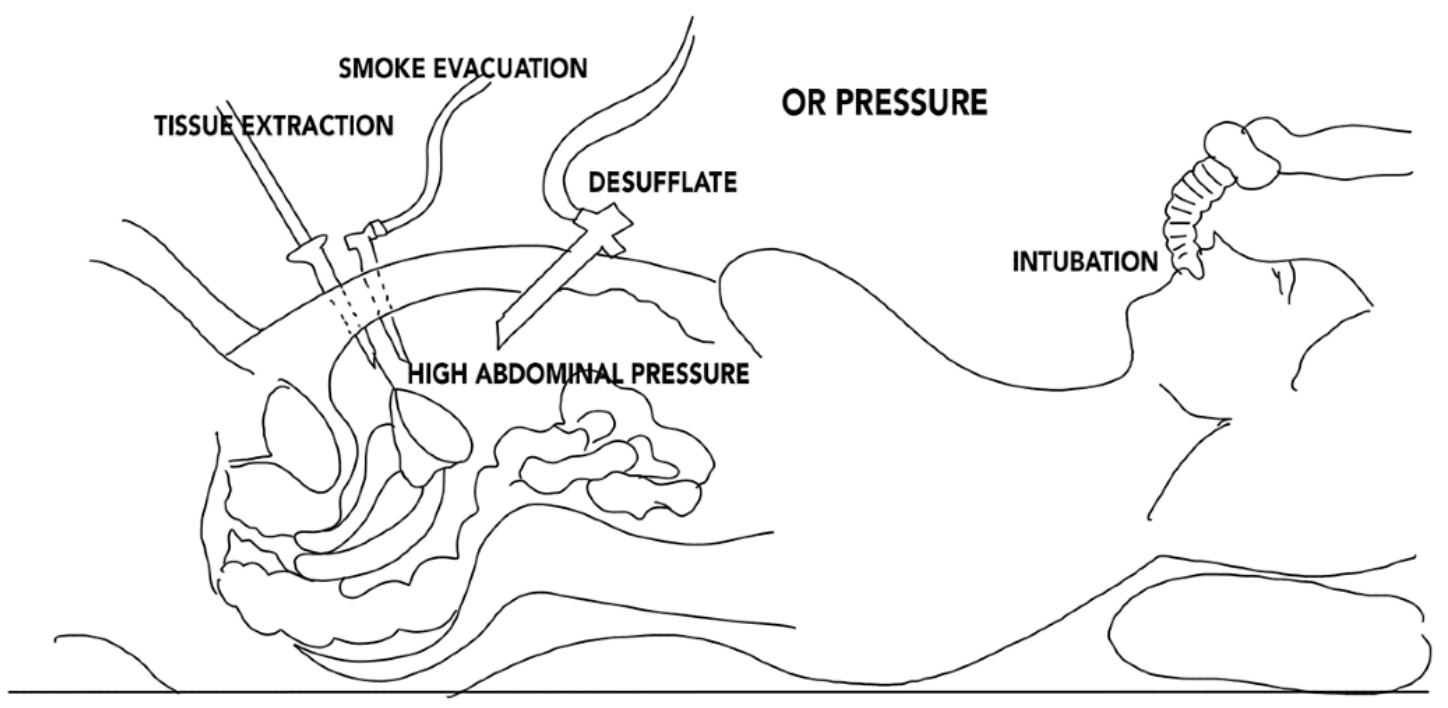

\section{Methods}

To provide insight into the possible risks of the abovementioned contaminating routes, we believe a scoping review is most suited. A scoping review allows a broader search and answers multiple questions while still performing a systematic search [20]. Because we expected few results from a search on COVID-19 and laparoscopy, we performed five additional searches for the contamination route and viruses in general.

\section{Systematic Search}

The literature search was performed on April 24, 2020, by searching the PubMed, CINAHL, and Embase databases. We then added gray literature from Google Scholar and local expertise and handbooks from the authors themselves from China, Italy, Spain, the United Kingdom, and the Netherlands. The search string can be found in Multimedia Appendix 1. The five additional questions were:

1. What is the effect of operating room pressure on the contamination risk of COVID-19?

2. What is known about the additional risk during intubation and extubation?

3. Does smoke evacuation during laparoscopic surgery increase the risk of the spread of COVID-19 particles?

4. Is anything known about tissue extraction during laparoscopic surgery on a patient with COVID-19?

5. Does desufflation of the abdomen after laparoscopic surgery create airborne aerosols that endanger health care providers?

\section{Inclusion Criteria}

Types of studies included were trials, reviews, case studies or series, and other descriptive studies concerning contamination of health care providers during (laparoscopic) surgery in the operating theater. We also included expert opinions if they added additional insight to the current literature.

\section{Exclusion Criteria}

We excluded society and professional association statements about COVID-19 if they did not add any new information. We did use them to snowball their references. We also excluded commentaries such as letters to the editor and papers not written in English.

\section{Study Selection}

Working independently and in duplicate, reviewers RDL and NB screened all record titles and abstracts. Potentially eligible abstracts and abstracts with disagreement or insufficient information were screened in full text. Disagreements were addressed by discussion of the full text.

\section{Results}

\section{Literature Search}

Figure 2 shows a flowchart of the literature search and results. The initial search identified 2007 records, of which 59 concerned COVID-19. After excluding 1740 records based on their title and abstract, we assessed 267 full-text papers for eligibility. Papers were excluded because they discussed a treatment therapy or diagnostic method $(118 / 267,44.2 \%)$, did not provide any new information (society statements, letters to the editor and others) $(30 / 267,11.2 \%)$, were not related to our question $(12 / 267,4.5 \%)$ or were not available in English (9/267, 3.4\%). After hand-searching the papers and society statements, we were left with 60 papers for this review. Of these 60 papers, 21 (35\%) concerned COVID-19, and 39 (65\%) discussed our questions in regard to other viral transmissions. We will now discuss the results for each of the five proposed questions. 
Figure 2. Preferred Reporting Items for Systematic Reviews and Meta-Analyses flow diagram of the literature search and results.

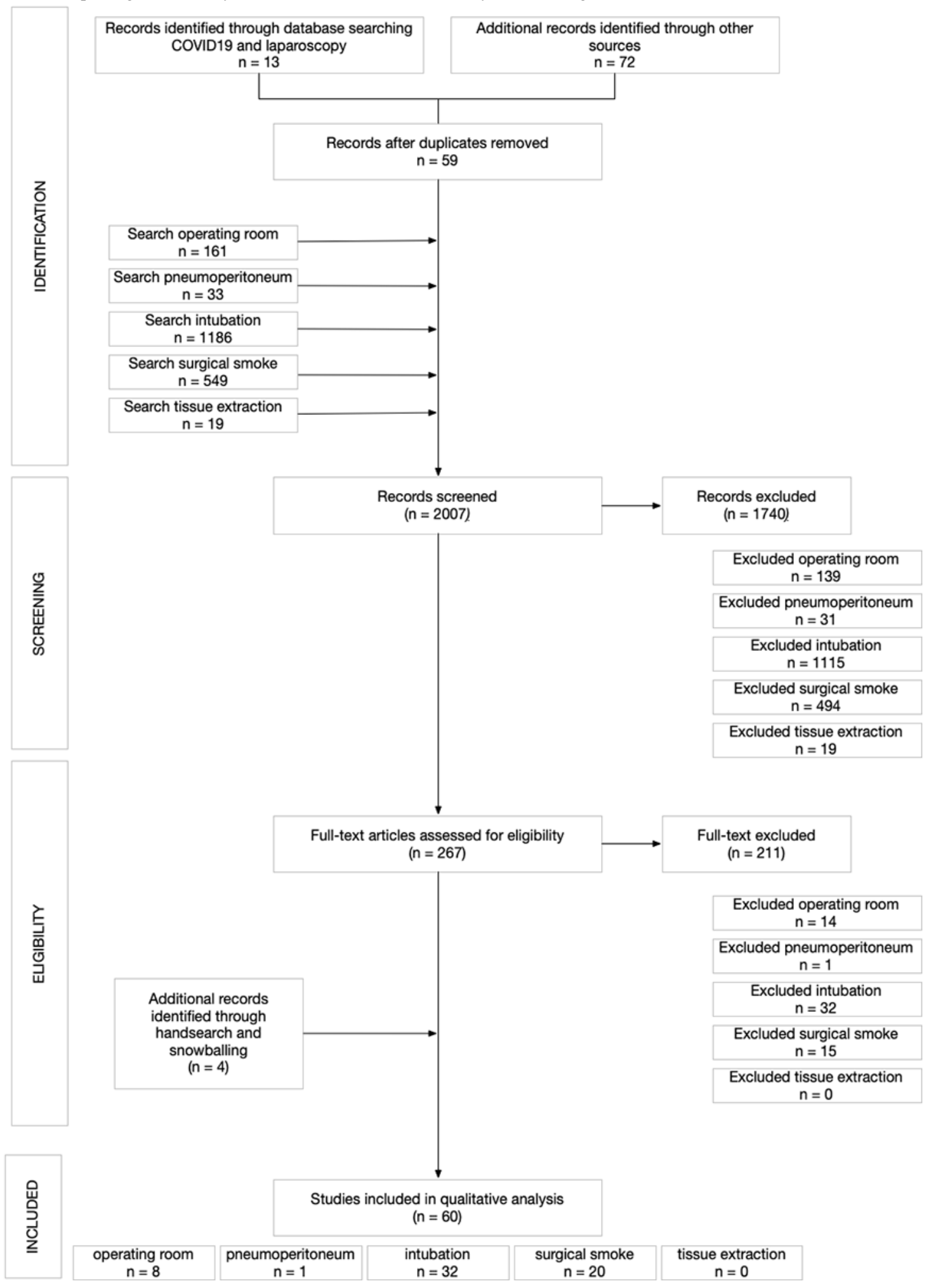

\section{What is the Effect of Operating Room Pressure on the Contamination Risk of COVID-19?}

experience with COVID-19 in Wuhan [11], and all studies were based on theoretical risks (see Table 1).

We found 8 papers discussing the effects of OR safety and the spread of virus DNA. Only 1 paper actually discussed the 
Table 1. Literature reports concerning viral transmission in operating rooms.

\begin{tabular}{|c|c|c|c|c|c|}
\hline Study & Country of study & Design & Location and year of evaluation & Pathogen evaluated & $\begin{array}{l}\text { Study quality } \\
\left(\text { GRADE }^{\mathrm{a}}\right)\end{array}$ \\
\hline Zhao et al [21] & China & Retrospective cohort study & Wuhan 2020 & SARS-CoV-2 ${ }^{b}$ & Low \\
\hline Pei et al [22] & China & Case-control study & Peking 2003 & SARS $^{\mathrm{c}}$ & Low \\
\hline Kamming et al [23] & Canada & Experience paper & Toronto 2003 & SARS & Low \\
\hline Chee et al [24] & Singapore & Experience paper & Singapore 2003 & SARS & Low \\
\hline Tien et al [25] & Canada & Case series & Toronto 2003 & SARS & Low \\
\hline Park et al [26] & South Korea & Experience paper & Sungkyunjkwan 2015 & MERS $^{d}$ & Low \\
\hline Beasley et al [27] & United States & Opinion paper & Washington 2004 & Smallpox & Low \\
\hline Santos de Silva et al [28] & Brazil & Case report & Vale dos Sinos 2014 & Adenovirus & Low \\
\hline
\end{tabular}

${ }^{\mathrm{a}}$ GRADE: Grading of Recommendations, Assessment, Development, and Evaluations.

${ }^{\mathrm{b}}$ SARS-CoV-2: severe acute respiratory syndrome coronavirus 2.

${ }^{\mathrm{c}} \mathrm{SARS}$ : severe acute respiratory syndrome.

${ }^{\mathrm{d}}$ MERS: Middle Eastern respiratory syndrome.

An OR with a negative pressure environment is ideal to reduce dissemination of the virus by preventing air from escaping the OR [11]. Both the Society of American Gastrointestinal and Endoscopic Surgeons (SAGAS) and the American Society of Gastrointestinal Endoscopy advise that surgery be performed in negative pressure ORs [29,30]. However, a standard OR is usually designed to be at positive pressure relative to the surrounding air. Tien et al [25] reported that during the severe acute respiratory syndrome (SARS) outbreak, surgical procedures were performed within airborne isolation Intensive Care Unit rooms and with additional PPE precautions. This eliminated the risk of intrafacility transport and avoided the need to make environmental modifications to the operating room. Other papers discuss the same contamination route with SARS and Middle Eastern respiratory syndrome (MERS) [22-24,26]. Beasley et al [27] discussed even more isolation strategies in the case of surgery on patients with smallpox.

In Singapore, dedicated separate ORs for surgery on patients with COVID-19 have been installed. The aim was to reduce the risk of contamination of other ORs and patients. Each OR had its own ventilation system with an integrated high-efficiency particulate air (HEPA) filter. The traffic and flow of contaminated air were minimized by locking all doors to the OR during surgery, with only one possible route for entry and exit via the scrub room [11].

Wax et al [31] provided practical recommendations to decrease viral spread when managing a patient infected with COVID-19. Their advice is to convert operating rooms to negative pressure environments with airflow changes.

\section{What is Known About the Additional Risk During Intubation and Extubation?}

Thirteen papers were found discussing intubation and extubation of patients with COVID-19 (see Table 2). Another 19 papers discuss the risk of intubation for health care providers for viruses other than severe acute respiratory syndrome coronavirus 2 (SARS-CoV-2, Multimedia Appendix 2). 
Table 2. Literature concerning intubation and SARS-CoV-2 virus in 2020.

\begin{tabular}{llll}
\hline Study & Region & Design & Main topic or result \\
\hline Cook [32] & United Kingdom & Narrative review & Purpose and use of PPE \\
Wax [31] & Canada & Review & Anesthesia guidelines \\
Heinzerling [33] & United States & Case series & $3 / 121(24.8 \%)$ of health care professionals tested positive \\
Meng [34] & China & Experience paper & $29 \%$ of hospitalized COVID-19 ${ }^{\mathrm{b}}$ patients were health care \\
& & & providers \\
Sorbello [35] & Italy & Experience paper & High level PPE for aerosol-generating procedures \\
Yao [36] & China & Experience paper & Anesthesia advice for intubation \\
Zhao [21] & China & Retrospective cohort study & Anesthetic management guidelines \\
Zuo [37] & China & Experience paper & Anesthesia guidelines \\
Giwa [38] & Italy & Experience paper & Complete COVID-19 overview \\
Greenland [39] & United States & Review & Intubation advice \\
Kim [40] & South Korea & Expert opinion & Anesthesia advice \\
Au Yong [41] & Singapore & Experience paper & Intubation advice \\
Zhang [42] & China & Case series & No health care providers infected \\
\hline
\end{tabular}

${ }^{\mathrm{a} P P E}$ : personal protective equipment.

${ }^{\mathrm{b}}$ COVID-19: coronavirus disease.

Two reviews from Cook et al [32] and Wax et al [31] provide a great overview of current knowledge and stress the increased risk to health care providers during intubation and extubation. A case series by van Heinzerling [33] shows that 3/121 health care providers $(2.5 \%)$ tested positive after assisting intubation.

Zucco at al [43] warn that the anesthesia professionals and intensivists have the highest risk of exposure to respiratory droplets during intubation and extubation. They provide a 10-point list of precautions that should be taken into account when intubating or extubating patients with COVID-19 [44]. Again, Wax et al [31] advise that high-risk aerosol-generating procedures, such as intubation, not be performed in a positive pressure environment. Won et al [11] advise the use of at least a National Institute for Occupational Safety and Health (NIOSH)-certified N95 respirator, eye protection (either goggles or a full face shield), cap, gown, and gloves. As transmission remains possible despite N95 protection, staff participating in aerosol-generating procedures can wear a powered air purifying respirator (PAPR). Repici et al [45] suggest additional PPE during endoscopic procedures but does not provide additional insight into the risks of intubation.

Learning from other experiences, 16 studies stress the increased risk for health care providers during intubation from the 2003 SARS period (Multimedia Appendix 2). Pei et al [22] show that the odds ratio (OR) that a health care provider will be infected is 30.8. While others show lower numbers (Rabout et al [46]
2.79 and Tran et al [47] 6.6), they all label intubation as a very high-risk procedure for health care providers.

\section{Does Smoke Evacuation During Laparoscopic Surgery Increase the Risk of the Spread of COVID-19 Particles?}

We found 25 papers discussing the effects of surgical smoke on health care providers. However, none of these papers is specific to COVID-19. A review from Mowbay et al [48] from 2013 included 20 studies and showed the diverse outcomes of these studies; they concluded that infective virus DNA can be found in the smoke plume, but the risk to OR staff is unproven. We found 19 studies not mentioned in the Mowbay review (see Table 3) that also showed diverse results. In Korea, Kwak et al [49] found hepatitis B DNA in surgical smoke in 10/11 cases; however, Waynandt [50] did not find any human papillomavirus (HPV) in 28 cases of $\mathrm{CO}_{2}$ laser plume. However, another study [51] shows that laparoscopic surgery is associated with better preservation of the immune system than open surgery. This results in a decreased incidence of infectious complications. A systematic review concerning surgical smoke during open surgery [48] shows that in terms of infection risk, 6/20 (30\%) of the studies assessed surgical smoke for the presence of viruses, with only 1 study (5\%) positively identifying viral DNA in laser-derived smoke. This has been shown for HPV DNA $[52,53]$. 
Table 3. Literature concerning surgical smoke plumes.

\begin{tabular}{|c|c|c|c|c|c|}
\hline Study & Country, year & Design & Pathogen evaluated & Type of smoke & Positive results \\
\hline Mowbray et al [48] & Multiple, 2013 & Systematic review & $\begin{array}{l}\mathrm{HPV}^{\mathrm{a}} \text {, compounds, cells, } \\
\text { particles }\end{array}$ & $\begin{array}{l}\text { Diathermy, laser, ultrasonic- } \\
\text { derived smoke }\end{array}$ & 20 studies included \\
\hline $\begin{array}{l}\text { Subbarayan et al } \\
{[54]}\end{array}$ & United States, 2019 & Case series & HPV16 & Laparoscopic electrosurgery & $0 / 6$ cases \\
\hline Neumann et al [55] & Germany, 2017 & $\begin{array}{l}\text { Prospective pilot se- } \\
\text { ries }\end{array}$ & HPV & $\begin{array}{l}\text { Loop electrosurgical excision } \\
\text { procedure }\end{array}$ & $4 / 24$ cases \\
\hline Dodhia et al [56] & United States, 2017 & Case series & HPV & KTP laser & $0 / 12$ fibers \\
\hline Kashima et al [57] & United States, 2016 & Case series & HPV & $\mathrm{CO}_{2}$ laser & $17 / 30$ cases \\
\hline Garden et al [58] & United States, 2015 & Animal study & Papillomavirus & $\mathrm{CO}_{2}$ laser & $3 / 3$ cases \\
\hline Kwak et al [49] & Korea, 2014 & Case series & Hepatitis B & Laparoscopic electrosurgery & $10 / 11$ cases \\
\hline Manson [59] & United States, 2013 & Review & HPV & $\mathrm{CO}_{2}$ laser & 4 studies included \\
\hline Weynandt et al [50] & Germany 2010 & Case series & HPV & $\mathrm{CO}_{2}$ laser, argon plasma & $0 / 28$ cases \\
\hline Taravella et al [60] & United States, 1998 & Experiment & Polio virus & Excimer laser & $2 / 2$ cases \\
\hline Hughes et al [61] & United States, 1997 & Case series & HPV & Erbium YAG laser & $0 / 5$ cases \\
\hline Hagen et al [62] & United States, 1997 & Experiment & Pseudorabies virus & Excimer laser & $0 / 20$ cases \\
\hline Gloster et al [63] & United States, 1995 & Survey & HPV & $\mathrm{CO}_{2}$ laser & $31 / 570$ reports \\
\hline Jewett et al [64] & United States, 1992 & Experiment & Hemoglobin & Drill aerosols & 5 of 5 cases \\
\hline Starr et al [65] & United States, 1992 & Experiment & $\begin{array}{l}\text { Simian immunodeficien- } \\
\text { cy virus }\end{array}$ & $\mathrm{CO}_{2}$ laser & 0 of 5 cases \\
\hline Baggish et al [52] & United States, 1991 & Case series & HIV & $\mathrm{CO}_{2}$ laser & 0 of 12 cases \\
\hline Hallmo et al [66] & Norway, 1990 & Case report & HPV & Erbium YAG laser & 1 of 1 cases \\
\hline Andre et al [67] & France, 1990 & Case report & HPV & $\mathrm{CO}_{2}$ laser & 2 of 2 cases \\
\hline Sawchuk et al [68] & United States, 1988 & Case series & HPV & $\mathrm{CO}_{2}$ laser & 4 of 8 cases \\
\hline Bellina et al [69] & United States, 1982 & Experiment & HPV & $\mathrm{CO}_{2}$ laser & No viable virus \\
\hline
\end{tabular}

${ }^{\mathrm{a}} \mathrm{HPV}$ : human papillomavirus.

\section{Is Anything Known About Tissue Extraction During Laparoscopic Surgery on a Patient With COVID-19?}

We found no studies found concerning this subject. The only studies that we found concerned malignant cells; however, those were out of the scope of this review. One study [70] showed that during laparoscopic surgery, $48.5 \%$ of surgeons' masks, $29.5 \%$ of assisting surgeons' masks, and $31.8 \%$ of scrub nurses' masks were positive for either visible or visually enhanced blood contamination. This demonstrates that wearing masks is of great importance, even when performing laparoscopic surgery.

\section{Does Desufflation of the Abdomen After Laparoscopic Surgery Create Airborne Aerosols That Endanger Health Care Providers?}

One case study discussed the desufflation of $\mathrm{CO}_{2}$ gas used during laparoscopic rectal surgery [71]. SAGES recently stated that there is a good possibility of viral contamination during laparoscopy; they added, "While it is unknown whether coronavirus shares these properties, it has been established that other viruses can be released during laparoscopy with carbon dioxide." However, this has only been shown in smoke, not clear $\mathrm{CO}_{2}$ [72].

In one study, the effects of COVID-19 on the strategy for colorectal cancer patients is discussed. The authors especially recommend that natural orifice specimen extraction surgery and transanal total mesorectal excision should be performed with caution during the epidemic period because fecal-oral transmission and aerosol transmission during this type of surgery have not been excluded. A protective stoma should reasonably be carried out, and the protection of OR personnel should be strengthened [73].

\section{Discussion}

There is some existential consensus in the literature that intubation and extubation are high-risk procedures for health care providers. Studies have shown ORs as high as 30, stressing the importance of proper PPE during those procedures [22]. Literature suggests that intubation and extubation should preferably be performed in a low-pressure environment with protective gear for the health care providers. A reasonable number of studies show that surgical smoke contains viral DNA 
and that health care providers should avoid inhaling it. The infectiousness of tissue extraction and the insufflation gas itself is absolutely unknown, and all advice is at least "arguable" (see Table 4).

When current knowledge does not help us any further, we are faced with a dilemma. Should we follow the conservative route and provide extensive PPE and prevent surgery at all costs? This may sound like the safe option; however, performing surgery wearing a PAPR [11] may not even be possible. In addition, delaying surgery may cause a patient more harm due to disease progression. Also, as COVID-19 continues to spread, resources are getting low, and it might not be possible to provide each health care provider with proper PPE. In that case, we should start to distribute resources where they are needed most, but also where the evidence provides insight into their effectiveness.

Table 4. Overview of proposed questions and evidence.

\begin{tabular}{lll}
\hline Transmission route & Available evidence & Advice \\
\hline Positive pressure $\mathrm{OR}^{\mathrm{a}}$ & Minimal & Turn off positive pressure, prepare several negative pressure ORs \\
Intubation/extubation & Minimal & Level III protection, should not be performed in positive pressure OR \\
Smoke evacuation & Minimal & Use a proper filter in a closed vacuum system \\
Tissue extraction & None & Use masks and screens/goggles at minimum \\
Desufflation of abdomen & None & Use a proper filter and a closed system \\
\hline
\end{tabular}

${ }^{\mathrm{a} O R}$ : operating room.

The Handbook of COVID-19 Prevention and Treatment compiled by the First Affiliated Hospital, Zehjang University School of Medicine [74], has not been peer-reviewed and published in the literature; however, it does provide important lessons from previous outbreaks. The authors consider any kind of surgery to be high risk and advise level III protection during surgery (ie, surgical cap, N95 protective mask, work uniform, disposable medical protective uniform, disposable latex gloves, and a full-face PAPR device), negative pressure operating rooms and several other hygiene precautions [74].

Textbox 1 provides a summary of our recommendations.

Textbox 1. Summary of care advice for laparoscopic surgery during the COVID-19 pandemic. COVID-19: coronavirus disease. CT: computerized tomography. PCR: polymerase chain reaction. PPE: personal protective equipment.

- $\quad$ Postpone elective surgery.

- Consider screening every patient who needs emergency surgery for COVID-19 either by PCR swab or CT scan of the thorax.

- Dedicate specific operating rooms to patients with COVID-19.

- Turn off positive pressure/create negative pressure ORs.

- Use Level III personal protective equipment during intubation and extubation.

- Consider Level III PPE but at least provide adequate mouth, face, and eye protection during surgery.

- Use proper filters and closed systems for smoke evacuation.

- Use proper filters and closed systems for $\mathrm{CO}_{2}$ desufflation.

- Do not perform transanal surgery.

- Consider faces as contaminated fluids.

\section{Comparing Open Surgery With Laparoscopic Surgery}

Surgery cannot always be avoided or delayed. Should we then perform open surgery instead of laparoscopic surgery? Evidence has shown the benefits of laparoscopic surgery in many cases and for multiple indications. Should we abandon these benefits for the patient in favor of lowering the risks for health care providers? The risks related to increased OR pressure and intubation are not changed during open surgery. The smoke evacuation may be even better controlled by laparoscopy then by open surgery, and the effects of tissue extraction and desufflation are completely unknown. Cauterization may be comparable; however, dissection by sharp instruments such as scissors and use of ligatures to prevent bleeding is more common during open surgery. Blood splash risks are estimated to be $48.5 \%$ [70] in laparoscopy and $45 \%$ in open surgery [75]. Northern Italian surgeons [76] prefer laparoscopy over laparotomy, making a case for a more controlled splatter and smoke environment. In their opinion, there is no reason to perform open surgery where laparoscopy is the first choice [76].

\section{Preventive Measures}

All studies emphasize the importance of protecting health care providers with adequate PPE whether they are performing surgery or a physical examination. However, there are diverse interpretations of how to use PPE. There are many studies examining, for example, face masks [77-79]. The debate is focused on the added value of giving the patient a mask [78] or 
which mask to use $[79,80]$. Some studies provide hospital-made protective gear solutions in case of limited resources [81] or show the added value of salt-covered masks [82]. Finally, studies that show the influence of transocular infection of influence advise the use of N95 protective gear for the eyes as well [83].

Focusing on other contamination routes, Hahn et al [84] showed that a built-in-filter trocar removes $>60 \%$ of hazardous molecules during laparoscopic rectal resection, and companies are registering these trocars. SAGAS and others advise that the use of devices to filter aerosolized particles in released $\mathrm{CO}_{2}$ should be strongly considered and that the high pressure in the OR should be turned off or, even better, low pressure ORs should be created. A few dedicated ORs should be created for the purpose of performing emergency surgery on patients who have or are at high risk for COVID-19.

Health care providers should think logically about tissue extraction, protect themselves and OR staff, desufflate the abdomen first, and not hesitate to increase the incision slightly rather than increasing the risk of the spread of aerosols. Finally, when desufflating, use of a filter should be considered or the same system as the smoke evacuation should be used.

\section{Conclusions}

To conclude, we would like to look forward. There is ongoing debate on the preoperative screening of asymptomatic patients and how to proceed when the peak of the crisis is over and elective surgeries can be performed again. To screen patients who are asymptomatic for COVID-19, earlier SARS-CoV-2 outbreak studies show higher sensitivity of computerized tomography (CT) scanning compared to polymerase chain reaction (PCR) swabbing $[85,86]$. However, more recent studies debate the actual added value in absolute numbers and the risks of false-positive outcomes even when using new classification systems $[87,88]$. Future studies are needed to provide proper advice about COVID-19 screening. Most of all, health care providers should use logic and common sense to protect themselves and others by performing surgery in a safe and protected environment. A global effort is being made to report on the experience and outcomes of surgical patients with COVID-19. The study protocol, registration, and details can be found at the website [89].

\section{Authors' Contributions}

The search was performed by RAdL and JH. Additional papers were added by JT, JZ, and PA. Local expertise was provided by $\mathrm{MM}, \mathrm{PB}, \mathrm{JB}$, and MC. All authors read and approved the final manuscript.

\section{Conflicts of Interest}

None declared.

\section{Multimedia Appendix 1}

Search string.

[DOCX File, 682 KB-Multimedia Appendix 1]

\section{Multimedia Appendix 2}

Study results for anesthesia and viral infection risk.

[DOCX File , 64 KB-Multimedia Appendix 2]

\section{References}

1. National Institutes of Health. 2020 May 14. Coronavirus (COVID-19) URL: https://www.nih.gov/health-information/ coronavirus [accessed 2020-05-15]

2. World Health Organization. WHO Coronavirus Disease (COVID-19) Dashboard URL: https://covid19.who.int [accessed 2020-05-15]

3. Mizumoto K, Chowell G. Estimating Risk for Death from 2019 Novel Coronavirus Disease, China, January-February 2020. Emerg Infect Dis 2020 Mar 13;26(6) [FREE Full text] [doi: 10.3201/eid2606.200233] [Medline: $\underline{32168464]}$

4. Médecins Sans Frontières. 2020 Mar 16. Help and solidarity needed in Europe to protect medical staff from COVID-19 URL: https://www.msf.org/covid-19-urgent-help-needed-across-european-borders-protect-medical-staff [accessed 2020-05-15]

5. Wu Y, Chen C, Chan Y. The outbreak of COVID-19. J Chin Med Assoc 2020;83(3):217-220. [doi: 10.1097/jcma.0000000000000270]

6. Wang J, Zhou M, Liu F. Reasons for healthcare workers becoming infected with novel coronavirus disease 2019 (COVID-19) in China. J Hosp Infect 2020 May; 105(1):100-101 [FREE Full text] [doi: 10.1016/j.jhin.2020.03.002] [Medline: 32147406]

7. Centers for Disease Control and Prevention. Information for Healthcare Professionals about Coronavirus (COVID-19) URL: https://www.cdc.gov/coronavirus/2019-ncov/hcp/caring-for-patients.html [accessed 2020-05-15]

8. Wang W, Xu Y, Gao R, Lu R, Han K, Wu G, et al. Detection of SARS-CoV-2 in Different Types of Clinical Specimens. JAMA 2020 Mar 11 [FREE Full text] [doi: 10.1001/jama.2020.3786] [Medline: 32159775]

9. $\mathrm{Ng} \mathrm{K}$, Poon BH, Kiat Puar TH, Shan Quah JL, Loh WJ, Wong YJ, et al. COVID-19 and the Risk to Health Care Workers: A Case Report. Ann Intern Med 2020 Mar 16. [doi: 10.7326/120-0175] 
10. Centers for Disease Control and Prevention. Interim U.S. Guidance for Risk Assessment and Public Health Management of Healthcare Personnel with Potential Exposure in a Healthcare Setting to Patients with Coronavirus Disease 2019 (COVID-19) URL: https://www.cdc.gov/coronavirus/2019-ncov/hcp/guidance-risk-assesment-hcp.html [accessed 2020-05-15]

11. Wong J, Goh QY, Tan Z, Lie SA, Tay YC, Ng SY, et al. Preparing for a COVID-19 pandemic: a review of operating room outbreak response measures in a large tertiary hospital in Singapore. Can J Anaesth 2020 Jun;67(6):732-745 [FREE Full text] [doi: 10.1007/s12630-020-01620-9] [Medline: 32162212]

12. Di Saverio S, Khan M, Pata F, Ietto G, De Simone B, Zani E, et al. Laparoscopy at all costs? Not now during COVID-19 and not for acute care surgery and emergency colorectal surgery. J Trauma Acute Care Surg 2020:1. [doi: 10.1097/ta.0000000000002727]

13. Royal College of Surgeons of Englaind. Updated Intercollegiate General Surgery Guidance on COVID-19 URL: https:/ /www.rcseng.ac.uk/coronavirus/joint-guidance-for-surgeons-v2/ [accessed 2020-05-18]

14. Wang L, Wang Y, Ye D, Liu Q. Review of the 2019 novel coronavirus (SARS-CoV-2) based on current evidence. Int J Antimicrob Agents 2020 Mar 19:105948 [FREE Full text] [doi: 10.1016/j.ijantimicag.2020.105948] [Medline: 32201353]

15. Kampf G, Todt D, Pfaender S, Steinmann E. Persistence of coronaviruses on inanimate surfaces and their inactivation with biocidal agents. J Hosp Infect 2020 Mar;104(3):246-251 [FREE Full text] [doi: 10.1016/j.jhin.2020.01.022] [Medline: 32035997]

16. van Doremalen N, Bushmaker T, Morris D, Holbrook M, Gamble A, Williamson B, et al. Aerosol and Surface Stability of SARS-CoV-2 as Compared with SARS-CoV-1. N Engl J Med 2020 Apr 16;382(16):1564-1567 [FREE Full text] [doi: 10.1056/NEJMc2004973] [Medline: 32182409]

17. American Society of Anesthesiologists. 2020 Mar 17. ASA-APSF Joint Statement on Non-Urgent Care During the COVID-19 Outbreak URL: https://www.asahq.org/about-asa/newsroom/news-releases/2020/03/ asa-apsf-joint-statement-on-non-urgent-care-during-the-covid-19-outbreak [accessed 2020-05-18]

18. European Society for Gynaecological Endoscopy. ESGE Recommendations on Gynaecological Endoscopic Surgery during Covid-19 Outbreak URL: https://esge.org/wp-content/uploads/2020/03/Covid19StatementESGE.pdf [accessed 2020-05-15]

19. American Association of Gynecologic Laparoscopists. 2020 Mar 27. COVID-19: Joint Statement on Minimally Invasive Gynecologic Surgery 2020 URL: https://www.aagl.org/news/ covid-19-joint-statement-on-minimally-invasive-gynecologic-surgery/ [accessed 2020-05-18]

20. Munn Z, Peters MDJ, Stern C, Tufanaru C, McArthur A, Aromataris E. Systematic review or scoping review? Guidance for authors when choosing between a systematic or scoping review approach. BMC Med Res Methodol 2018 Nov 19;18(1):143 [FREE Full text] [doi: 10.1186/s12874-018-0611-x] [Medline: 30453902]

21. Zhao S, Ling K, Yan H, Zhong L, Peng X, Yao S, et al. Anesthetic Management of Patients with COVID 19 Infections during Emergency Procedures. J Cardiothorac Vasc Anesth 2020 May;34(5):1125-1131 [FREE Full text] [doi: 10.1053/j.jvca.2020.02.039] [Medline: 32178954]

22. Pei L, Gao Z, Yang Z, Wei D, Wang S, Ji J, et al. Investigation of the influencing factors on severe acute respiratory syndrome among health care workers. Beijing Da Xue Xue Bao Yi Xue Ban 2006 Jun 18;38(3):271-275 [FREE Full text] [Medline: 16778970$]$

23. Kamming D, Gardam M, Chung F. Anaesthesia and SARS. Br J Anaesth 2003 Jun;90(6):715-718 [FREE Full text] [doi: 10.1093/bja/aeg173] [Medline: 12765882]

24. Chee VWT, Khoo ML, Lee SF, Lai YC, Chin NM. Infection control measures for operative procedures in severe acute respiratory syndrome-related patients. Anesthesiology 2004 Jun;100(6):1394-1398. [doi: 10.1097/00000542-200406000-00010] [Medline: 15166557]

25. Tien H, Chughtai T, Jogeklar A, Cooper A, Brenneman F. Elective and emergency surgery in patients with severe acute respiratory syndrome (SARS). Can J Surg 2005 Feb;48(1):71-74 [FREE Full text] [Medline: 15757044]

26. Park J, Yoo SY, Ko J, Lee SM, Chung YJ, Lee J, et al. Infection Prevention Measures for Surgical Procedures during a Middle East Respiratory Syndrome Outbreak in a Tertiary Care Hospital in South Korea. Sci Rep 2020 Jan 15;10(1):325 [FREE Full text] [doi: 10.1038/s41598-019-57216-x] [Medline: 31941957]

27. Beasley A, Kenenally S, Mickel N, Korowicki K, McCann S, Arundell J, et al. Treating Patients With Smallpox in the Operating Room. AORN Journal 2004 Oct 01;80(4):681-689. [doi: 10.1016/s0001-2092(06)61322-7]

28. Vanessa dos Santos da Silva J, Henrique de Mello M, Staggemeier R, Henzel A, Rigotto C, Spilki FR. Adenovirus presence in surfaces and equipment from ambulatories, internship units, and operating rooms in a Brazilian hospital. Am J Infect Control 2014 Jun;42(6):693-694. [doi: 10.1016/j.ajic.2014.02.007] [Medline: 24837126]

29. ASGE Quality Assurance in Endoscopy Committee, Calderwood A, Day LW, Muthusamy VR, Collins J, Hambrick RD, et al. ASGE guideline for infection control during GI endoscopy. Gastrointest Endosc 2018 May;87(5):1167-1179. [doi: 10.1016/j.gie.2017.12.009] [Medline: 29573782]

30. American Society for Gastrointestinal Endoscopy. Joint GI Society Message: COVID-19 Clinical Insights for Our Community of Gastroenterologists and Gastroenterology Care Providers URL: https://www.asge.org/home/ joint-gi-society-message-covid-19 [accessed 2020-05-18] 
31. Wax RS, Christian MD. Practical recommendations for critical care and anesthesiology teams caring for novel coronavirus (2019-nCoV) patients. Can J Anaesth 2020 May;67(5):568-576 [FREE Full text] [doi: 10.1007/s12630-020-01591-x] [Medline: $\underline{\text { 32052373] }}$

32. Cook TM. Personal protective equipment during the coronavirus disease (COVID) 2019 pandemic - a narrative review. Anaesthesia 2020 Apr 04. [doi: 10.1111/anae.15071] [Medline: 32246849]

33. Heinzerling A, Stuckey MJ, Scheuer T, Xu K, Perkins KM, Resseger H, et al. Transmission of COVID-19 to Health Care Personnel During Exposures to a Hospitalized Patient - Solano County, California, February 2020. MMWR Morb Mortal Wkly Rep 2020 Apr 17;69(15):472-476 [FREE Full text] [doi: 10.15585/mmwr.mm6915e5] [Medline: 32298249]

34. Meng L, Qiu H, Wan L, Ai Y, Xue Z, Guo Q, et al. Intubation and Ventilation amid the COVID-19 Outbreak. Anesthesiology 2020;132(6):1317-1332. [doi: 10.1097/aln.0000000000003296]

35. Sorbello M, El-Boghdadly K, Di Giacinto I, Cataldo R, Esposito C, Falcetta S, Società Italiana di Anestesia Analgesia Rianimazione e Terapia Intensiva (SIAARTI) Airway Research Group, The European Airway Management Society. The Italian coronavirus disease 2019 outbreak: recommendations from clinical practice. Anaesthesia 2020 Jun;75(6):724-732. [doi: 10.1111/anae.15049] [Medline: 32221973]

36. Yao W, Wang T, Jiang B, Gao F, Wang L, Zheng H, Collaborators. Emergency tracheal intubation in 202 patients with COVID-19 in Wuhan, China: lessons learnt and international expert recommendations. Br J Anaesth 2020 Apr 10 [FREE Full text] [doi: 10.1016/j.bja.2020.03.026] [Medline: $\underline{32312571]}$

37. Zuo M, Huang Y, Ma W, Xue Z, Zhang J, Gong Y, Chinese Society of Anesthesiology Task Force on Airway Management. Expert Recommendations for Tracheal Intubation in Critically ill Patients with Noval Coronavirus Disease 2019. Chin Med Sci J 2020 Feb 27. [doi: 10.24920/003724] [Medline: 32102726]

38. Giwa AL, Desai A, Duca A. Novel 2019 coronavirus SARS-CoV-2 (COVID-19): An updated overview for emergency clinicians. Emerg Med Pract 2020 May 01;2(COVID-19):A. [Medline: 32207910]

39. Greenland JR, Michelow MD, Wang L, London MJ. COVID-19 Infection: Implications for Perioperative and Critical Care Physicians. Anesthesiology 2020 Jun;132(6):1346-1361 [FREE Full text] [doi: 10.1097/ALN.0000000000003303] [Medline: 32195698]

40. Kim HJ, Ko JS, Kim T. Recommendations for anesthesia in patients suspected of COVID-19 Coronavirus infection. Korean J Anesthesiol 2020 Apr;73(2):89-91 [FREE Full text] [doi: 10.4097/kja.20110] [Medline: 32172550]

41. Au Yong PS, Chen X. Reducing droplet spread during airway manipulation: lessons from the COVID-19 pandemic in Singapore. Br J Anaesth 2020 Apr 15 [FREE Full text] [doi: 10.1016/j.bja.2020.04.007] [Medline: 32312572]

42. Zhang W, Du R, Li B, Zheng X, Yang X, Hu B, et al. Molecular and serological investigation of 2019-nCoV infected patients: implication of multiple shedding routes. Emerg Microbes Infect 2020;9(1):386-389 [FREE Full text] [doi: 10.1080/22221751.2020.1729071] [Medline: 32065057]

43. Zucco L, Levy N, Ketchandji D, Aziz M, Ramachandran SK. Anesthesia Patient Safety Foundation. 2020 Feb 12. Perioperative Considerations for theel Coronavirus (COVID-19) URL: https://www.apsf.org/news-updates/ perioperative-considerations-for-the-2019-novel-coronavirus-covid-19/ [accessed 2020-05-18]

44. Zucco L, Levy N, Ketchandji D, Aziz M, Ramachandran SK. Anesthesia Patient Safety Foundation. Recommendations for Airway Management in a Patient with Suspected Coronavirus (2019-nCoV) Infection URL: https://www.apsf.org/wp-content/ uploads/news-updates/2020/apsf-coronavirus-airway-management-infographic.pdf [accessed 2020-05-18]

45. Repici A, Maselli R, Colombo M, Gabbiadini R, Spadaccini M, Anderloni A, et al. Coronavirus (COVID-19) outbreak: what the department of endoscopy should know. Gastrointest Endosc 2020 Mar 14 [FREE Full text] [doi: 10.1016/j.gie.2020.03.019] [Medline: 32179106]

46. Raboud J, Shigayeva A, McGeer A, Bontovics E, Chapman M, Gravel D, et al. Risk factors for SARS transmission from patients requiring intubation: a multicentre investigation in Toronto, Canada. PLoS One 2010 May 19;5(5):e10717 [FREE Full text] [doi: 10.1371/journal.pone.0010717] [Medline: 20502660]

47. Tran K, Cimon K, Severn M, Pessoa-Silva CL, Conly J. Aerosol generating procedures and risk of transmission of acute respiratory infections to healthcare workers: a systematic review. PLoS One 2012;7(4):e35797 [FREE Full text] [doi: 10.1371/journal.pone.0035797] [Medline: 22563403]

48. Mowbray N, Ansell J, Warren N, Wall P, Torkington J. Is surgical smoke harmful to theater staff? a systematic review. Surg Endosc 2013 Sep;27(9):3100-3107. [doi: 10.1007/s00464-013-2940-5] [Medline: 23605191]

49. Kwak HD, Kim S, Seo YS, Song K. Detecting hepatitis B virus in surgical smoke emitted during laparoscopic surgery. Occup Environ Med 2016 Dec;73(12):857-863. [doi: 10.1136/oemed-2016-103724] [Medline: 27484956]

50. Weyandt GH, Tollmann F, Kristen P, Weissbrich B. Low risk of contamination with human papilloma virus during treatment of condylomata acuminata with multilayer argon plasma coagulation and $\mathrm{CO}_{2}$ laser ablation. Arch Dermatol Res 2011 Mar;303(2):141-144. [doi: 10.1007/s00403-010-1119-3] [Medline: 21249502]

51. Targarona EM, Balagué C, Knook MM, Trías M. Laparoscopic surgery and surgical infection. Br J Surg 2000 May;87(5):536-544. [doi: 10.1046/j.1365-2168.2000.01429.x] [Medline: 10792307]

52. Baggish MS, Poiesz BJ, Joret D, Williamson P, Refai A. Presence of human immunodeficiency virus DNA in laser smoke. Lasers Surg Med 1991;11(3):197-203. [doi: 10.1002/1sm.1900110302] [Medline: 1907345] 
53. Sood AK, Bahrani-Mostafavi Z, Stoerker J, Stone IK. Human Papillomavirus DNA in LEEP Plume. Infectious Diseases in Obstetrics and Gynecology 1994;2(4):167-170. [doi: 10.1155/s1064744994000591]

54. Subbarayan RS, Shew M, Enders J, Bur AM, Thomas SM. Occupational exposure of oropharyngeal human papillomavirus amongst otolaryngologists. Laryngoscope 2019 Nov 11. [doi: 10.1002/lary.28383] [Medline: 31710711]

55. Neumann K, Cavalar M, Rody A, Friemert L, Beyer DA. Is surgical plume developing during routine LEEPs contaminated with high-risk HPV? A pilot series of experiments. Arch Gynecol Obstet 2018 Feb;297(2):421-424. [doi: 10.1007/s00404-017-4615-2] [Medline: 29236173]

56. Dodhia S, Baxter PC, Ye F, Pitman MJ. Investigation of the presence of HPV on KTP laser fibers following KTP laser treatment of papilloma. Laryngoscope 2018 Apr;128(4):926-928. [doi: 10.1002/lary.27018] [Medline: 29171656]

57. Kashima HK, Kessis T, Mounts P, Shah K. Polymerase chain reaction identification of human papillomavirus DNA in CO2 laser plume from recurrent respiratory papillomatosis. Otolaryngol Head Neck Surg 1991 Feb;104(2):191-195. [doi: 10.1177/019459989110400206] [Medline: 1848926]

58. Garden JM, O'Banion MK, Bakus AD, Olson C. Viral disease transmitted by laser-generated plume (aerosol). Arch Dermatol 2002 Oct;138(10):1303-1307. [doi: 10.1001/archderm.138.10.1303] [Medline: 12374535 ]

59. Manson LT, Damrose EJ. Does exposure to laser plume place the surgeon at high risk for acquiring clinical human papillomavirus infection? Laryngoscope 2013 Jun;123(6):1319-1320. [doi: 10.1002/lary.23642] [Medline: 23703382]

60. Taravella MJ, Weinberg A, May M, Stepp P. Live virus survives excimer laser ablation. Ophthalmology 1999 Aug 01;106(8):1498-1499. [doi: 10.1016/s0161-6420(99)90442-6]

61. Hughes PS, Hughes AP. Absence of human papillomavirus DNA in the plume of erbium:YAG laser-treated warts. J Am Acad Dermatol 1998 Mar;38(3):426-428. [doi: 10.1016/s0190-9622(98)70500-6]

62. Hagen KB, Kettering JD, Aprecio RM, Beltran F, Maloney RK. Lack of Virus Transmission by the Excimer Laser Plume. Am J Ophthalmol 1997 Aug;124(2):206-211. [doi: 10.1016/s0002-9394(14)70785-8]

63. Gloster HM, Roenigk RK. Risk of acquiring human papillomavirus from the plume produced by the carbon dioxide laser in the treatment of warts. J Am Acad Dermatol 1995 Mar;32(3):436-441. [doi: 10.1016/0190-9622(95)90065-9]

64. Jewett D, Heinsohn P, Bennett C, Rosen A, Neuilly C. Blood-containing aerosols generated by surgical techniques: a possible infectious hazard. Am Ind Hyg Assoc J 1992 Apr;53(4):228-231. [doi: 10.1080/15298669291359564] [Medline: $1529914]$

65. Starr J, Kilmer S, Wheeland R. Analysis of the carbon dioxide laser plume for simian immunodeficiency virus. J Dermatol Surg Oncol 1992 Apr;18(4):297-300. [doi: 10.1111/j.1524-4725.1992.tb03674.x] [Medline: 1560153]

66. Hallmo P, Naess O. Laryngeal papillomatosis with human papillomavirus DNA contracted by a laser surgeon. Eur Arch Otorhinolaryngol 1991 Oct;248(7):425-427. [doi: 10.1007/bf01463570]

67. Andre P, Orth G, Evenou P, Guillaume JC, Avril MF. Risk of papillomavirus infection in carbon dioxide laser treatment of genital lesions. J Am Acad Dermatol 1990 Jan;22(1):131-132. [doi: 10.1016/s0190-9622(08)80016-3]

68. Sawchuk WS, Weber PJ, Lowy DR, Dzubow LM. Infectious papillomavirus in the vapor of warts treated with carbon dioxide laser or electrocoagulation: Detection and protection. Journal of the American Academy of Dermatology 1989 Jul;21(1):41-49. [doi: 10.1016/s0190-9622(89)70146-8]

69. Bellina JH, Stjernholm RL, Kurpel JE. Analysis of plume emissions after papovavirus irradiation with the carbon dioxide laser. J Reprod Med 1982 May;27(5):268-270. [Medline: 6809938]

70. Wines MP, Lamb A, Argyropoulos AN, Caviezel A, Gannicliffe C, Tolley D. Blood splash injury: an underestimated risk in endourology. J Endourol 2008 Jun;22(6):1183-1187. [doi: 10.1089/end.2008.0052] [Medline: 18498231]

71. Pawar T, Pokharkar A, Gori J, Pandey D, Rohila J, Dsouza A, et al. The Technique and Justification for Minimally Invasive Surgery in COVID-19 Pandemic: Laparoscopic Anterior Resection for Near Obstructed Rectal Carcinoma. J Laparoendosc Adv Surg Tech A 2020 May;30(5):485-487. [doi: 10.1089/lap.2020.0241] [Medline: 32315244]

72. Pryor A. Society of American Gastrointestinal and Endoscopic Surgeons. 2020 Mar 30. SAGES and EAES Recommendations Regarding Surgical Response to COVID-19 Crisis URL: https://www.sages.org/recommendations-surgical-response-covid-19/ [accessed 2020-05-18]

73. Yu G, Lou Z, Zhang W. Several suggestion of operation for colorectal cancer under the outbreak of Corona Virus Disease 19 in China. Article in Chinese. Zhonghua Wei Chang Wai Ke Za Zhi 2020 Feb 19;23(3):9-11. [doi: 10.3760/cma.j.issn.1671-0274.2020.03.002] [Medline: 32074719]

74. First Affiliated Hospital, Zhejiang University School of Medicine. 2020 Mar 18. Handbook of COVID-19 Prevention and Treatment URL: https://www.researchgate.net/publication/339998871 Handbook of COVID-19 Prevention and Treatment [accessed 2020-05-18]

75. Davies C, Khan M, Ghauri A, Ranaboldo C. Blood and Body Fluid Splashes During Surgery - The Need for Eye Protection and Masks. Ann R Coll Surg Engl 2007 Nov;89(8):770-772. [doi: 10.1308/003588407x209301] [Medline: 17999818]

76. Spinelli A, Pellino G. COVID-19 pandemic: perspectives on an unfolding crisis. Br J Surg 2020 Mar 19. [doi: 10.1002/bjs.11627] [Medline: $\underline{\text { 32191340] }}$

77. Blachere FM, Lindsley WG, McMillen CM, Beezhold DH, Fisher EM, Shaffer RE, et al. Assessment of influenza virus exposure and recovery from contaminated surgical masks and N95 respirators. J Virol Methods 2018 Oct;260:98-106 [FREE Full text] [doi: 10.1016/j.jviromet.2018.05.009] [Medline: $\underline{\text { 30029810] }}$ 
78. Milton DK, Fabian MP, Cowling BJ, Grantham ML, McDevitt JJ. Influenza virus aerosols in human exhaled breath: particle size, culturability, and effect of surgical masks. PLoS Pathog 2013 Mar;9(3):e1003205 [FREE Full text] [doi: 10.1371/journal.ppat.1003205] [Medline: 23505369]

79. Zhou SS, Lukula S, Chiossone C, Nims RW, Suchmann DB, Ijaz MK. Assessment of a respiratory face mask for capturing air pollutants and pathogens including human influenza and rhinoviruses. J Thorac Dis 2018 Mar;10(3):2059-2069. [doi: 10.21037/jtd.2018.03.103]

80. Makison Booth C, Clayton M, Crook B, Gawn J. Effectiveness of surgical masks against influenza bioaerosols. J Hosp Infect 2013 May;84(1):22-26. [doi: 10.1016/j.jhin.2013.02.007] [Medline: 23498357]

81. Lai YY, Chang CM. A carton-made protective shield for suspicious/confirmed COVID-19 intubation and extubation during surgery. Anesth Analg 2020:1. [doi: 10.1213/ane.0000000000004869]

82. Quan F, Rubino I, Lee S, Koch B, Choi H. Universal and reusable virus deactivation system for respiratory protection. Sci Rep 2017 Jan 04;7:39956 [FREE Full text] [doi: 10.1038/srep39956] [Medline: 28051158]

83. Bischoff WE, Reid T, Russell GB, Peters TR. Transocular entry of seasonal influenza-attenuated virus aerosols and the efficacy of $n 95$ respirators, surgical masks, and eye protection in humans. J Infect Dis 2011 Jul 15;204(2):193-199 [FREE Full text] [doi: 10.1093/infdis/jir238] [Medline: 21673029]

84. Malkowski J. Google Patents. 2019. Air purifier for laparoscopic surgery URL: https://patents.google.com/patent/ US20190328983A1/en [accessed 2020-05-18]

85. Ai T, Yang Z, Hou H, Zhan C, Chen C, Lv W, et al. Correlation of Chest CT and RT-PCR Testing in Coronavirus Disease 2019 (COVID-19) in China: A Report of 1014 Cases. Radiology 2020 Feb 26:200642. [doi: 10.1148/radiol.2020200642] [Medline: $\underline{\text { 32101510] }}$

86. Bernheim A, Mei X, Huang M, Yang Y, Fayad ZA, Zhang N, et al. Chest CT Findings in Coronavirus Disease-19 (COVID-19): Relationship to Duration of Infection. Radiology 2020 Feb 20:200463. [doi: 10.1148/radiol.2020200463] [Medline: 32077789]

87. Revel M, Parkar AP, Prosch H, Silva M, Sverzellati N, Gleeson F, European Society of Radiology, European Society of Thoracic Imaging. COVID-19 patients and the radiology department - advice from the European Society of Radiology (ESR) and the European Society of Thoracic Imaging (ESTI). Eur Radiol 2020 Apr 20 [FREE Full text] [doi: 10.1007/s00330-020-06865-y] [Medline: 32314058]

88. Prokop M, van Everdingen W, van Rees Vellinga T, Quarles van Ufford J, Stöger L, Beenen L, "COVID-19 Standardized Reporting" Working Group of the Dutch Radiological Society. CO-RADS - A categorical CT assessment scheme for patients with suspected COVID-19: definition and evaluation. Radiology 2020 Apr 27:201473. [doi: 10.1148/radiol.2020201473] [Medline: 32339082]

89. NIHR Global Health Research Unit on Global Surgery. About CovidSurg URL: https://globalsurg.org/covidsurg/ [accessed 2020-05-15]

\author{
Abbreviations \\ COVID-19: coronavirus disease \\ CT: computerized tomography \\ GRADE: Grading of Recommendations, Assessment, Development, and Evaluations \\ HEPA: integrated high-efficiency particulate air \\ HPV: human papillomavirus \\ MERS: Middle Eastern respiratory syndrome \\ OR: operating room \\ PCR: polymerase chain reaction \\ PPE: personal protective equipment \\ SAGAS: Society of American Gastrointestinal and Endoscopic Surgeons
}

Edited by G Eysenbach; submitted 27.03.20; peer-reviewed by M Nomali, E Da Silva; comments to author 20.04.20; revised version
received 07.05.20; accepted 13.05.20; published 23.06.20
Please cite as:
de Leeuw RA, Burger NB, Ceccaroni M, Zhang J, Tuynman J, Mabrouk M, Barri Soldevila P, Bonjer HJ, Ankum P, Huirne J
COVID-19 and Laparoscopic Surgery: Scoping Review of Current Literature and Local Expertise
JMIR Public Health Surveill 2020;6(2):e18928
URL: $\underline{\text { http://publichealth.jmir.org/2020/2/e18928/ }}$
doi: $\underline{10.2196 / 18928}$
PMID: $\underline{32406853}$


CRobert Adrianus de Leeuw, Nicole Birgit Burger, Marcello Ceccaroni, Jian Zhang, Jurriaan Tuynman, Mohamed Mabrouk, Pere Barri Soldevila, Hendrik Jaap Bonjer, Pim Ankum, Judith Huirne. Originally published in JMIR Public Health and Surveillance (http://publichealth.jmir.org), 23.06.2020. This is an open-access article distributed under the terms of the Creative Commons Attribution License (https://creativecommons.org/licenses/by/4.0/), which permits unrestricted use, distribution, and reproduction in any medium, provided the original work, first published in JMIR Public Health and Surveillance, is properly cited. The complete bibliographic information, a link to the original publication on http://publichealth.jmir.org, as well as this copyright and license information must be included. 